\title{
РАЗДЕЛУІІ. ИСКУССТВОВЕДЕНИЕ
}

\author{
Гостеева А.B. \\ Иконография «праздников» Васильевского чина и их стилистические особенности \\ в сравнении с «праздниками» Благовещенского собора Московского Кремля и \\ Троицкого собора Троице-Сергиевой лавры \\ Санкт-Петербургский государственный университет, Российская Федерация \\ (Россия, Санкт-Петербург)
}

doi: $10.18411 / \mathrm{sr}-10-10-2018-16$

idsp: 000001:sr-10-10-2018-16

\section{Аннотация}

В данной статье будут рассмотрены пять икон из праздничного ряда Васильевского чина, на которых сохранился живописный слой начала XV в.: «Благовещение», «Сретение», «Крещение», «Сошествие во ад» и «Вознесение». В качестве сравнения будут приведены иконы со сходными сюжетами из иконостасов Благовещенского собора Московского Кремля и Троицкого собора Троице-Сергиевой лавры.

Ключевые слова: иконопись, иконография, XV век, праздники, Северовосточная Русь, московская школа.

Данная статья посвящена сравнительному анализу праздничных чинов из иконостасов Успенского собора во Владимире (т.н. Васильевский чин) (нач. XV в.), Благовещенского собора Московского Кремля (нач. XV в.) и Троицкого собора ТроицеСергиевой лавры (1427 г.). Данные памятники выбраны для сравнения в виду того, что это первые высокие иконостасы на Руси, то есть они послужили «отправной точкой» для сложения иконографии оформления иконостаса как комплекса. Все три иконостаса являются основными комплексами северо-восточной Руси в первой трети XV в., включающими в себя «праздники».

На иконе «Благовещение» из Васильевского чина справа мы видим Богородицу в зеленом хитоне и вишневом мафории, сидящую на алой подушке на скамье без спинки. Напротив нее в резком порыве изображен архангел Гавриил, который благословляющим жестом правой руки обращается к Марии. Действие разворачивается на фоне архитектурного стаффажа. В иконе «Благовещение» из Васильевского чина использован извод так называемого «Благовещения с пряжей», где Богородица представлена сидящей, ее голова склонена, в левой руке она держит веретено, а правая развернута к Гавриилу. В иконе «Благовещение» из Благовещенского собора Московского Кремля использован тот же извод, но в данном случае голова Богородицы поднята и вместе с тем поднята ее левая рука с веретеном. В сравнении с «Благовещением» из Васильевского чина заметно, что иконы восходят к разным образцам одного извода, что следует из разных жестов Богородицы и цвета одежд Гавриила. Подобный извод был популярен в позднепалеологовское время, и встречается, например, во фресках ц. Богородицы Перивлепты в Мистре (1380 г.). В «Благовещении» из Троицкого собора заметно, что икона очень близка к Васильевскому «Благовещению», на что указывает та же склоненная голова Богоматери, ее опущенная левая рука и правая, обращенная к Гавриилу. Также совпадает стремительная поза архангела. Можно предположить, что иконы восходят к одной прориси.

Для иконы «Благовещение» из Васильевского чина в качестве стилистических особенностей можно выделить некоторую статичность, застылость композиции, несмотря на то, что архангел Гавриил изображен в стремительном движении, обращенном к Марии. Еще больше момент остановившегося движения подчеркивает 
поза Богородицы: она склонила голову и как бы ждет, что скажет ей Гавриил. Складки одежд архангела выполнены в довольно жесткой графичной манере, они лишь подчеркивают то, что Гавриил уже почти остановился, хотя мгновение назад он еще летел. Одежды Марии полностью окутывают ее, тем самым фигура Богоматери становится как бы лишенной объема, мы видим только силуэт, созданный одеждами, но не видим плоти. Архитектура на заднем плане выполнена объемно, мы ее видим глубину, что еще больше подчеркивает плоскостность фигур. В иконе из Благовещенского собора мы видим более мелкий, дробный рисунок, удлиненные пропорции фигур. Здесь также велика роль линии, которая стремится создать четкие, ровные контуры. Наряду с этим, присуща и некоторая резкость, угловатость, что особенно заметно в рисунке складок развевающихся подолов одежд архангела. Архитектура изображена дольно объемно, поэтому на ее фоне четко очерченные фигуры кажутся плоскими. Для иконы выбрана теплая светлая цветовая гамма, где единственным ярким пятном является изображение киноварного покрова над фигурами Богоматери и Гавриила. Для «Благовещения» из Троицкого собора характерна силуэтность фигур, они очерчены четким ясным контуром. Здесь линия становится более мягкой и плавной, нет угловатости, которую можно было заметить в иконах двух других чинов. В иконе использован очень теплый светлый колорит, фигура архангела почти сливается с желто-золотым фоном. Как и в благовещенской иконе здесь тоже выделяется красный покров, но в троицкой иконе красный цвет мягкий и приглушенный, он не выделяется из общего цветового решения.

Сюжет «Сретения» разворачивается на фоне храма, пространство которого символизируют архитектурные формы по бокам и соединяющая их красная ткань. Подобные формы весьма характерны для XV в. (например, фрески ц. Пантанассы в Мистре, 1428 г.). В центре находится киворий, перед которым справа стоят СимеонБогоприимец в зеленом хитоне и охристом гиматии и пророчица Анна в зеленом хитоне и мафории со свернутым свитком в руке. Слева от кивория расположены фигуры Богоматери в зеленом хитоне и вишневом мафории и Иосифа Обручника в зеленом хитоне и оливковом гиматии, держащего в руках двух жертвенных голубей. Здесь использован вариант иконографии, где Младенец одет в желто-золотистую рубашку и уже находится на руках Симеона, но не касается его щекой. Данная схема была распространена до середины XIII в., однако нередко встречалась и в позднепалеологовских памятниках. Для «Сретения» из Благовещенского собора был использован другой извод, где Младенец еще находится на руках Богородицы, фигура Анны расположена не за Симеоном, а за Марией, киворий смещен вправо. В иконе из Троицкого собора композиция повторяет Васильевское «Сретение» с Симеоном, держащим Младенца на руках, но здесь она более камерная, что выражается в соприкосновении щек Симеона и Младенца. Скорее всего, был использован один извод, но в данном случае нельзя говорить об одних прорисях, так как отличается положение головы пророчицы Анны (в иконе из Успенского собора она склонена) и по-разному решено архитектурное оформление фона, хотя изображены одни и те же формы.

В качестве стилистических особенностей «Сретения» из Васильевского чина можно выделить некую статичность поз, их тяжеловесность. Однако присутствует и некоторый момент динамики, что подчеркивается четко очерченными контурами фигур, линейным ритмом складок покрова престола. За счет довольно плоскостного изображения архитектурного фона, фигуры, вынесенные на передний край ковчега, кажутся достаточно объемными. Мастер использовал весьма сдержанный колорит, но киноварный покров престола выделяется из общего цветового решения, тем самым, подчеркивая композиционный центр сцены. Для благовещенской иконы «Сретение» можно выделить вытянутые, удлиненные пропорции фигур. Плавность и ритмичность линий особо подчеркивается тем, что фигуры расположены на почти одинаковом расстоянии друг от друга, и их головы, увенчанные нимбами, находятся на одной высоте. Для «Сретения» из Троицкого собора также характерны удлиненные 
пропорции фигур, но здесь уже нет такой ритмичности, контуры не такие резкие и угловые, как в «васильевской» иконе. Особенно выделяется довольно плоскостная, линеарная манера в рисунке фигур, но в то же время, лики выписаны очень объемно и живописно. Для икон из Благовещенского и Троицкого собора характерен светлый теплый колорит.

В иконе «Крещение» действие происходит на фоне скалистых горок и вод Иордана. Христос изображен фронтально, в белой повязке. Его правая рука сложена в благословляющем жесте и лежит на животе, а левая опущена на бедро. Справа от Спасителя изображена фигура Иоанна Предтечи, но она не так изогнута, как в двух других иконах (из Благовещенского собора Московского Кремля и Троицкого собора Троице-Сергиевой лавры). Креститель одет в темно-зеленую власяницу и такого же цвета гиматий. Слева от Христа расположены фигуры четырех ангелов, двое из которых смотрят на воды Иордана, а двое другие - наверх, на нисходящий Святой Дух в виде голубя. В васильевском «Крещении» использован краткий тип иконографии, где нет иудеев, крестящихся в Иордане вместе со Спасителем, но на иконе присутствуют персонификации Иордана и моря, в воде плавают рыбы, что говорит о внимании к деталям. В «Крещении» из Благовещенского собора та же поза Христа, что и в иконе из Васильевского чина, но заметно, насколько сильно отличаются фигуры Крестителя. Если в иконе из Успенского собора он как бы шагает ко Христу и лишь слегка склоняется к нему, то в кремлевской иконе он статичен, его фигура сильно изогнута. Также отличны и одежды Предтечи: в васильевском «Крещении» мы видим власяницу и зеленый гиматий, а в московской иконе Креститель изображен в желтом хитоне и зеленом гиматии. Для иконы из Благовещенского собора характерно отсутствие мелких деталей. «Крещение» из Троицкого собора почти полностью повторяет икону из Благовещенского собора: та же согбенная поза Предтечи и его одежды, та же поза Христа, повторено изображение группы ангелов. Лещадки и расположение растительности в точности повторяют кремлевскую икону. Вероятно, для этих двух икон была использована одна прорись.

Манера, в которой выполнена икона «Крещение» из Васильевского чина, является наиболее живописной из тех, которые мы видим в других четырех иконах из Успенского собора. Здесь мы также наблюдаем четко очерченные контуры фигур, но роль линии не является доминирующей. Большое внимание мастер уделяет объемной проработке форм за счет светотени, причем лики трактованы более объемно, чем фигуры, что особенно заметно в изображении ангелов. По сравнению с другими четырьмя иконами чина именно в «Крещении» ярче всего проявляется роль цвета: здесь он служит одним из способов придания объема фигурам. Наряду с этим, колорит «Крещения» является наиболее глубоким и насыщенным. В «Крещении» из Благовещенского собора мы видим совершенно другую манеру: здесь, как и в других иконах этого чина, велика роль линии. Она создает плавные контуры фигур, но вместе с тем используется и для детальной проработки складок одежд. Чувствуется дробность, некоторая детализированность в рисунке, присуща декоративность, манеру нельзя назвать монументальной и живописной. Колорит теплый, неяркий, даже темные воды Иордана не выделяются из общего цветового решения. Касательно иконы из Троицкого собора довольно сложно говорить о стилистике, в виду ее плохой сохранности. Однако можно заметить, что здесь также использованы тонкие графичные линии для создания силуэтов и разделки одежд. Заметно, что фигуры довольно плоские, на их фоне горки на заднем плане кажутся более объемными. Для иконы характерен теплый светлый колорит, преобладают охры, фигуры почти сливаются с охристо-желтым фоном.

В иконе «Сошествие во ад» из Васильевского чина мы видим, что действие разворачивается в пещере ада. Христос в охристо-желтых одеждах стоит на попранных вратах и правой рукой вытягивает за запястье коленопреклоненного Адама. Всю фигуру Спасителя окружает мандорла в виде четырех концентрических окружностей, через которые проходит свет от Христа. Рядом с Адамом стоит Ева, а за ее спиной группа праведников. По правую руку от Спасителя представлена группа ветхозаветных 
царей, возглавляемая Давидом и Соломоном. Здесь мы наблюдаем более архаичный вариант иконографии, где Адам и Ева изображены с одной стороны от Христа, хотя со второй половины XIV в. распространяется вариант иконографии, где Адам и Ева находятся по разные стороны от Христа. Также в данной иконе выбран развернутый иконографический тип, для которого характерно большое число персонажей, что тоже стало распространенным со второй половины XIV в. Для иконы из Васильевского чина был выбран извод, где Христос изображен в резком повороте и вытягивает за руку Адама, а во второй держит свиток как символ проповеди. В иконе из Благовещенского собора использован вариант иконографии, где Адам и Ева находятся по разные стороны от Христа. В отличие от васильевского «Сошествия во ад», где Христос повернут к праведникам, в этой иконе он повернут к царям. Также изменено и расположение фигуры Христа: если в иконе из Успенского собора Спаситель попирает врата ада, то здесь он находится как бы на краю. В иконе из Троицкого собора был использован тот же иконографический тип, что и в васильевском «Сошествии во ад»: Христос повернут к Адаму, стоящему в группе праведников вместе с Авелем, и вытягивает его за руку, а рядом с этой же стороны расположена коленопреклоненная фигура Евы. Вероятнее всего, образцом для иконы 1425-27 гг. послужило именно васильевское «Сошествие во ад».

В качестве стилистических особенностей «Сошествия во ад» из Успенского собора можно выделить статичность композиции, некоторую жесткость контуров. Фигуры изображены довольно плоскостно, объем виден лишь там, где мастер подчеркивает его за счет складок одежд и белильных высветлений на них. Здесь нет динамичных поз и жестов, очертания фигур угловаты, что особенно видно в изображении Спасителя. Довольно крупные фигуры, занимающие две трети ковчега, смещены на первый план. В качестве фона мастер выполнил две почти симметричных горки, которые еще больше подчеркивают застылость и статичность композиции. Вероятно, именно в этой иконе из пяти сохранившихся «праздников» Васильевского чина представлен наиболее чистый и яркий колорит. Для иконы из Благовещенского собора характерны вытянутые пропорции фигур, их довольно близкое расположение друг к другу. Велика роль линии: она придает контурам некоторую жесткость, но в то же время и пластичность, подчеркивает локальность цвета. Также заметно отсутствие экспрессии и эмоциональности. В довольно приглушенном охристо-желтом колорите особенно выделяются киноварные одежды Евы, Давида и Соломона. В иконе из Троицкого собора мы также видим удлиненные пропорции фигур, главенствующую роль линии, которая создает четкие угловатые контуры. Здесь видна довольно графичная манера, однако лики прописаны очень объемно, с использованием нескольких слоев плавей. Цвет дан локальный пятнами, достаточно четко отделенными друг от друга. В целом колорит довольно бледный, цвета приглушенные, но среди них четко выделяются ярко-красные одежды Евы и ветхозаветных царей.

В иконе «Вознесение» многофигурная композиция делится на две неравные части: внизу изображена Богородица с апостолами и ангелами, а наверху медальон с Христом, поддерживаемый двумя ангелами. За Богородицей - два ангела, симметричных друг другу, указывающие наверх, на Христа. По правую руку от Богоматери изображена группа из шести апостолов, возглавляемая Петром. Левую группу, также из шести апостолов, возглавляет Павел. Над головами ангелов и апостолов видны горки и едва заметные следы двух деревьев. Христос изображен в желто-охристых одеждах. Его правая рука отведена в сторону в благословляющем жесте, а в левой - он держит свернутый свиток. Круглый медальон, в котором изображен Спаситель, состоит из трех концентрических окружностей. В иконе «Вознесение» из Васильевского чина представлен вариант иконографии, где Богоматерь изображена фронтально с раскрытыми перед грудью ладонями. Правой рукой она обращена к апостолу Петру, и это довольно редкий извод, который встречается на золотом окладе первой трети XV в. с иконы Богоматери Владимирской. В иконе из Благовещенского собора использован тот же извод и, скорее всего, у этих 
двух икон была одна прорись. Отличаются лишь небольшие детали. Например, цвет одежд некоторых апостолов и левого ангела, несущего «славу» с Христом, расположение деревьев. В иконе из Троице-Сергиевой лавры повторен тот же извод, что и в двух предыдущих: Богоматерь изображена фронтально, руки раскрыты ладонями перед собой, правая рука обращена к апостолу Петру. От иконы из Васильевского чина так же незначительно отличатся цветом апостольских одежд и отсутствием деревьев, которые, впрочем, могли присутствовать изначально, но были утрачены вместе с подлинным живописным слоем. Таким образом, можно говорить о том, что для всех трех икон «Вознесения», вероятно, была использована одна и та же прорись, которая могла несколько испортиться с течением времени. Чем и можно объяснить столько незначительные изменения в общей композиция для этих трех икон.

В качестве стилистических особенностей иконы «Вознесение» из Успенского собора можно выделить доминирующую роль линии. Ярче всего это проявляется в четко очерченных контурах фигур и в жесткой, ритмичной разделке складок одежд. Здесь почти нет мягких и плавных линий, рисунку присуща некоторая резкость и угловатость. Заметна статичность и застылость позы Богоматери, подчеркнутая симметричным расположением ангелов за ее спиной. Однако вместе с этим мы видим, в каких разнообразных позах и ракурсах представлены апостолы, несмотря на то, что они все смотрят наверх и обращены ко Христу. Мастер использовал достаточно сдержанный колорит с преобладанием светлых теплых тонов, «разбавленный» насыщенными зелеными оттенками. В иконе из Благовещенского собора заметно больше экспрессии, более разнообразно переданы эмоции апостолов, их фигуры стоят не так близко друг к другу. Фигуры вытянуты, их пропорции удлиненные, что особенно заметно в фигуре Богоматери. Для иконы характерен довольно мелкий, дробный рисунок, контуры еще более жесткие, чем в васильевском Вознесении. Иконы сходны по колориту, но в благовещенской иконе красный цвет яркий, насыщенный, в то время как в иконе из Успенского сбора выбраны более теплые, приглушенные оттенки. В иконе из Троицкого собора также заметны удлиненные пропорции фигур, но по трактовке композиции икона ближе к васильевскому «Вознесению»: апостолы стоят близко друг к другу, между ними почти нет пустого пространства. Здесь как и в двух других иконах велика роль линии и контура, присутствует некоторая угловатость, что особенно заметно в ангельских фигурах, несущих «славу» с Христом. В троицком «Вознесении» выбран довольно сдержанный теплый колорит, цвета неяркие, приглушенные.

В качестве стилистических черт, присущим всем пяти иконам Васильевского чина можно выделить: статичность, застылость композиции, расположение фигур у самого края, для фигур характерны укрупненные пропорции, задний фон не остается нейтральным или свободным, он закрыт архитектурными сооружениями или лещадками. Также можно говорить о доминирующей роли линии и контура (за исключением «Крещения») и светлом теплом колорите. Манеру нельзя назвать живописной, однако во всех иконах прослеживается тенденция довольно плоскостного написания фигур и объемной живописной моделировке ликов.

Таким образом, «праздники» Васильевского чина ближе к «праздникам» Троицкого собора, чем к московским. Иконографические типы васильевских «Благовещения», «Сретения» и «Сошествия во ад» были затем повторены в Троицком соборе. «Крещение» имеет иконографические особенности, которых нет в двух других, a «Вознесение» во всех трех соборах происходит с одной и той же прориси и почти никак не изменяется.

В целом, можно сказать, что стилистически чины довольно близки между собой, но каждый из них имеет свои специфические черты. При сравнении было выявлено, что для «праздников» всех трех чинов характерна главенствующая роль линии, отсутствие ярко выраженной экспрессии, использование светлой и теплой цветовой гаммы. Однако стоит выделить, что по сравнению с «праздниками» из Благовещенского и Троицкого соборов, где пропорции фигур сильно вытянуты, в васильевских 
«праздниках» фигуры кажутся несколько тяжеловесными и не такими легкими. Напротив, в благовещенских «праздниках» заметен мелкий, дробный рисунок и есть некоторая тенденция к декоративизации форм. Для «праздников» из Троицкого собора наряду с вытянутыми пропорциями характерна легкость, изящность форм и лаконизм.

$$
* * *
$$

1. Алпатов М.В. Андрей Рублев. М., 1959.

2. Антонова В. И., Мнева Н. Е. Каталог древнерусской живописи XI - начала XVIII вв. Опыт историкохудожественной классификации. Т. 1. М.: Искусство, 1963

3. Бобров Ю.Г. Основы иконографии древнерусской иконной живописи. СПб, 1995

4. Вейцман К. Ранние иконы // Вейцман К., Хадзидакис М., Миятев К., Радойчич С. Иконы на Балканах. София, Белград., 1967.

5. Демина Н.А. О связях Андрея Рублева и мастеров его круга с искусством и культурой Киевской и Владимиро-Суздальской Руси. // Андрей Рублев и его эпоха. Под ред. М.В. Алпатова. М., 1971.

6. Дудочкин Б. Н. Андрей Рублев. Биография. Произведения. Источники. Литература. // Художественная культура Москвы и Подмосковья XIV - начала XX веков. Сборник статей в честь Г. В. Попова. М., 2002.

7. Ильин М.А. Иконостас Успенского собора во Владимире Андрея Рублева // ДРИ: Художественная культура Москвы и прилегающих к ней княжеств. XIV-XVI вв. М., 1970.

8. Лазарев В.Н. Андрей Рублев и его школа. М., 1966.

9. Лазарев В.Н.Русская иконопись от истоков до начала XVI века. М., 1983.

10. Морозова Е. И. Эпистилии со сценами праздников в системе декорации византийской алтарной преграды (XII в.) // Актуальные проблемы теории и истории искусства: сб. науч. статей. Вып. 1. / Под ред. С.В. Мальцевой, Е.Ю. Станюкович-Денисовой. СПб.: НП-Принт, 2011.

11. Осташенко Е.Я. Андрей Рублев. Палеологовские традиции в московской школе живописи конца XIV первой трети XV века. М., 2005.

12. Покровский Н. В. Евангелие в памятниках иконографии: преимущественно византийский и русских. М.: Прогресс-традиция, 2001.

13. Смирнова Э.С. Иконы праздничного ряда из иконостаса Успенского собора во Владимире. // Зограф, №16. Белград, 1985.

14. Щенникова Л. А. Иконы в Благовещенском соборе Московского Кремля. Деисусный и праздничный ряды иконостаса: Каталог. М.: Красная площадь, 2004.

15. Walter C. A New Look at the Byzantine Sanctuary Barrier // REB. 1993. Vol. 51.

\section{Статкевич В.O. \\ Изображение свадеб в живописи Фландрии XVII века}

Санкт-Петербургский Государственный Университет (Россия, Санкт-Петербург)

doi: $10.18411 /$ sr-10-10-2018-17

idsp: 000001:sr-10-10-2018-17

\section{Аннотация}

В статье рассматривается появление и развитие изображений на сюжет свадебных торжеств в живописи Фландрии XVII века. Даётся описание и анализ ряда известных памятников и определяется круг мастеров, которые обращались к данному сюжету. Также выявляются характерные черты, присущие данным изображениям и хронологические рамки их развития.

Ключевые слова: свадьба, жанровая живопись, Фландрия, XVII век, характерные черты, преемственность.

Изображения свадебных торжеств не редки во фламандской живописи на протяжении всего XVII века. Уже во второй половине XVI века Питер Брейгель Старший обращался к изображению свадьбы и сопутствующих ей увеселений. Наряду с рождением и кончиной свадьба была ключевым моментом жизни простого человека. Это один из важнейших праздников для крестьян, на который собирались всем селением. Важный сакральный смысл этого события был наследием уходящего Средневековья. После 